\title{
Implementation of the Supervision Function on Public Sector Employees (Study at PT. PLN's South Sulawesi, Southeast Sulawesi and West Sulawesi Regions)
}

\author{
Nur Ilmiah Rivai \\ Ilmu Administrasi Negara, Universitas Pepabri Makassar \\ Email: dr.nurilmiah@gmail.com
}

(Received: December 12-2019; revised: February 15-2020; published: June 31-2020)

\begin{abstract}
Good supervision is needed at the Office of PT. PLN (Persero) in the South Sulawesi, Southeast Sulawesi and West Sulawesi Regions so that employees can work effectively and produce optimal work. The purpose of this study, is to analyze the supervisory function carried out at PT. PLN (Persero) South Sulawesi, Southeast Sulawesi and West Sulawesi Regions. This research method uses quantitative research with descriptive research type. Data collection techniques using questionnaires in the form of a checklist and using descriptive analysis techniques. The results of the study showed that the direct supervision conducted was quite good, while the direct supervision was quite good.
\end{abstract}

Keywords: Employee controlling; work effectively; supervision

\section{INTRODUCTION}

The organization is a gathering place for many people who have the same goal by working together to achieve that goal. In an organization must be able to manage activities that lead to the achievement of organizational goals (Dahlan et al., 2017; Hentika \& Setyowati, 2016; Jamaluddin et al., 2017; Prasodjo, 2019; Syukur \& Awaru, 2019; Wildana \& Awaru, 2018). In order for the organization to run effectively, it requires people who have the skills in accordance with their respective fields of work.

According to Suratman (2017) argues that organizational effectiveness can be expressed as the degree to which the organization achieves its objectives. Effectiveness is a broad concept and in its organization includes a variety of factors, so effectiveness is an important concept in organizational theory, because it can provide a picture of how far the achievement of targets in the organization.

The efforts that the organization can do to improve and maintain employee effectiveness is to carry out the oversight function as well as possible, as the result of Sufianto (2015) research at Samarinda District Office in Samarinda City and Paksi \& Prihartono (2019) at the Tirta Kencana Samarinda Regional Water Company (PDAM).

According to Siagian (1989), supervision is the process of observing all activities in the organization so that the activities they can carry out are guaranteed in accordance with a predetermined plan. Employees as people who think, plan and implement something in development, the development is demanded by a high level of effectiveness.

The offices of PT PLN (Persero) in the South Sulawesi, Southeast Sulawesi and West Sulawesi regions are companies engaged in electricity, serving the need for electricity for 
160| Jurnal Ilmiah Ilmu Administrasi Publik: Jurnal Pemikiran dan Penelitian Administrasi Publik Volume 10 Number 1, January - June 2020. Page 159-164

various layers of Indonesian society ranging from industry to households. The office has a vision that is, recognized as a world-class company that is growing, superior, and trusted by relying on human potential. To achieve this, the PT PLN (Persero) South Sulawesi, Southeast Sulawesi and West Sulawesi Offices need qualified staff and work effectively. Thus, good supervision is needed to be able to encourage employees to work harder and produce optimal work.

Based on the background description of the problems that have been raised, then the purpose of this study is to analyze the supervisory function performed on the employees of the Office of PT. PLN (Persero) South Sulawesi, Southeast Sulawesi and West Sulawesi Regions.

\section{METHOD}

The research location is in the Office of PT PLN (Persero) South Sulawesi, Southeast Sulawesi and West Sulawesi Secretariat Section. This research uses quantitative research with descriptive research type (Creswell, 2013). The population in this study were employees of PT. PLN (Persero South Sulawesi, Southeast Sulawesi and West Sulawesi (Sulselrabar) in the Secretariat Section, amounting to 34 people.

The data collection technique chosen was by using a questionnaire (questionnaire) using a checklist form. The questionnaire is equipped with a measurement scale to produce quantitative data. Likert scale that will be used in this study to measure the attitudes, opinions, and perceptions of employees or respondents at PT. PLN (Persero South Sulawesi, Southeast Sulawesi and West Sulawesi (Sulselrabar) in the Secretariat Section.

The research questionnaire created by this researcher was tested for validity and reliability before and after the study (Creswell \& Creswell, 2017). Test the validity using the help of SPSS software version 24.0. Validity testing is enough to compare the calculated value with Product Moment's rtable value (see Appendix). If the calculated value is abel rtable, then the indicator or statement of the questionnaire is said to be valid, and vice versa. Data is also said to be valid if the value of sig. (2-tailed) data $<0.05$.

\section{RESULT AND DISCUSSION}

To be able to provide a description of the supervisory function performed on the employees of the Office of PT. PLN (Persero) in the South Sulawesi, Southeast Sulawesi and West Sulawesi regions, the analysis in this study focused on 2 (two) predetermined supervision indicators, namely: (1) Direct supervision, in the form of: direct inspection, on the spot observation, and on the spot report; and (2) Indirect supervision, in the form of: oral reports and written reports.

\section{Direct supervision}

Direct supervision, in the form of: direct inspection, on the spot observation, and on the spot report (Fazakis et al., 2019; García Osma et al., 2019; Ju et al., 2019; Khosa et al., 2019). Related to direct supervision in the form of direct inspection, the statement about the leadership conducts direct supervision to subordinates, shows the respondent's answer stating Very Agree 
of $5.9 \%$, Agree of $47.1 \%$, Doubtful of $20.6 \%$, Less Agree of $23.5 \%$, and Disagree of $2.9 \%$. In a statement about superiors often reviewing the workspace of subordinates, shows the answers of respondents who stated Very Agree of 8.8\%, Agree of 47.1\%, Doubt of 17.6\%, Less Agree of $23.5 \%$, and Disagree by $2.9 \%$. And, in a statement of good supervision in case of irregularities / mistakes of subordinates, the supervisor will immediately reprimand, indicating the respondent's answer stating Very Agree of $17.6 \%$, Agree of $76.5 \%$, Doubts of $2.9 \%$, Less Agree of $2.9 \%$, and Disagree of $0.0 \%$.

Related to direct supervision in the form of on-the-spot observation, the statement about the leadership often makes direct observations at work before the activity is carried out, showing the respondents' answers stating Very Agree of 5.9\%, Agree of 41.2\%, Doubt of $26.5 \%$, Disagreeing at $26.5 \%$, and Disagreeing at $0.0 \%$. In the statement about the leader directly correcting subordinates if there are errors in work, shows the answers of respondents who stated Very Agree of 8.8\%, Agree of 67.6\%, Doubtful of 8.8\%, Less Agree of $11.8 \%$, and Disagree $2.9 \%$. And, the statement about superiors often discussing with subordinates when facing a very difficult job, shows the respondents' answers stating Very Agree of 20.6\%, Agree of $70.6 \%$, Doubtful of $5.9 \%$, Less Agree of 2, 9\%, and Disagree of $0.0 \%$.

Whereas, related to direct supervision in the form of on the spot report, the statement of the leadership directly receives reports on work from his subordinates or executors, showing the respondent's answers stating Very Agree of $11.8 \%$, Agree of $79.4 \%$, Doubt of $5.9 \%$, Disagreeing at $0.0 \%$, and Disagreeing at $2.9 \%$. And, in the statement of the leadership directly responding to the results of the work report, shows the answers of respondents who stated Very Agree of $8.8 \%$, Agree of $82.4 \%$, Doubt of $5.9 \%$, Less Agree of $2.9 \%$, and Disagreeing at $0.0 \%$.

Based on respondents' answers related to direct supervision at PT PLN Office. (Persero) The South Sulawesi, Southeast Sulawesi and West Sulawesi (Sulselrabar) Regions especially the Secretariat Section, shows that the direct supervision carried out is quite good. This is because there are still some respondents who answered Less Agree on the statement of superiors often reviewing subordinate workspaces, leaders often make direct observations on the spot before the activity is carried out, and on the leader's statement directly responds to the results of work reports. According to the direct supervision theory proposed by (Amanda et al., 2017; Syamsiar et al., 2018), namely direct inspection, on the spot observation, and on the spot report, if it is associated with the answers from respondents, it can be said that this research is not in line with the theory of Amanda, where the supervisor is indeed it should often review the work space of his subordinates, often make direct observations on the spot before the activity is carried out, and superiors directly provide responses to the results of work reports carried out by his subordinates.

Associated with indirect supervision in the form of a verbal report, in the statement of the leadership asking subordinates to report the results of their work verbally, showing respondents' answers stating Very Agree of $8.8 \%$, Agree of $76.5 \%$, Doubts of $8.8 \%$, Less Agree of $2.9 \%$, and Disagree of $2.9 \%$. And, in the statement of the leadership not responding to the reports of the work results of his subordinates, showed the answers of respondents who stated Very Agree of $2.9 \%$, Agree of 35.3\%, Doubtful of 35.3\%, Less Agree of 23.5\%, and Disagree of $2.9 \%$.

Meanwhile, related to indirect supervision in the form of a written report, in the statement of the leadership instructing his subordinates to make a report in writing, showing respondents' answers stating Very Agree of 8.8\%, Agree of 64.7\%, Doubts of 11, 8\%, Disagreeing at $11.8 \%$, 
162 | Jurnal Ilmiah Ilmu Administrasi Publik: Jurnal Pemikiran dan Penelitian Administrasi Publik Volume 10 Number 1, January - June 2020. Page 159-164

and Disagreeing at 2.9\%. And, the statements of subordinates working on the report were not in accordance with the instructions given, showing respondents' answers stating Very Agree of 2.9\%, Agree of 35.3\%, Doubtful of 17.6\%, Less Agree of 41.2\% , and Disagree 2.9\%.

Based on respondents' answers related to indirect supervision in the Office of PT. PLN (Persero) in the South Sulawesi, Southeast Sulawesi and West Sulawesi (Sulselrabar) regions, especially the Secretariat Section, shows that the indirect supervision carried out is quite good. This is because there are still a number of respondents who answered Agree on the statement of the leadership not responding to the reports of the work results of their subordinates and the statements of subordinates working on the report did not comply with the instructions given. According to the indirect supervision theory proposed by Pristiwaluyo \& Ab Hakim (2019), a verbal report and a written report if linked to the respondent's answer can be said that this research is not in line with the theory of the Pristiwaluyo, because superiors should instruct their subordinates to make reports in written and subordinate should make a report in accordance with instructions from their superiors.

\section{CONCLUSION}

Based on the results of the analysis and discussion that has been carried out, it can be concluded that supervision in the Office of PT. PLN (Persero) in South Sulawesi, Southeast Sulawesi and West Sulawesi (Sulselrabar) regions, especially the Secretariat, still needs to be improved based on respondents' answers to the supervisory function with direct and indirect monitoring indicators.

\section{REFERENCES}

Amanda, M. O., Salam, R., \& Saggaf, S. (2017). Pengaruh Supervisi Kepala Sekolah Terhadap Kinerja Guru Di SMK Negeri 1 Bungoro Kabupaten Pangkep. Prosiding Seminar Nasional Himpunan Sarjana Ilmu-Ilmu Sosial, 2, 149-154.

Creswell, J. W. (2013). Research Design: Qualitative Approach, Quantitative and Mixed. Yogyakarta: Student Library.

Creswell, J. W., \& Creswell, J. D. (2017). Research design: Qualitative, quantitative, and mixed methods approaches. Sage publications.

Dahlan, D., Hasim, D., \& Hamdan, H. (2017). Pengaruh Manajemen Sumber Daya Manusia dan Budaya Organisasi Terhadap Kualitas Pelayanan Pada Kantor Kecamatan Tamalate Kota Makassar. Jurnal Ad'ministrare, 4(2), 69-75.

Fazakis, N., Karlos, S., Kotsiantis, S., \& Sgarbas, K. (2019). A multi-scheme semi-supervised regression approach. Pattern Recognition Letters, 125, 758-765. https://doi.org/https://doi.org/10.1016/j.patrec.2019.07.022

García Osma, B., Mora, A., \& Porcuna-Enguix, L. (2019). Prudential supervisors' independence and income smoothing in European banks. Journal of Banking \& Finance, 102, 156-176. https://doi.org/https://doi.org/10.1016/j.jbankfin.2019.03.001

Hentika, N. P., \& Setyowati, E. (2016). Upaya Kementerian Agama Dan Non Government 
Organization (Ngo) Dalam Memperbaiki Manajemen Masjid Di Kota Malang. Jurnal Ad'ministrare, 3(1), 38-50.

Jamaluddin, J., Salam, R., Yunus, H., \& Akib, H. (2017). Pengaruh budaya organisasi terhadap kinerja pegawai pada dinas pendidikan provinsi sulawesi selatan. Jurnal Ad'ministrare, $4(1), 25-34$.

Ju, D., Huang, M., Liu, D., Qin, X., Hu, Q., \& Chen, C. (2019). Supervisory consequences of abusive supervision: An investigation of sense of power, managerial self-efficacy, and task-oriented leadership behavior. Organizational Behavior and Human Decision Processes, 154, 80-95. https://doi.org/https://doi.org/10.1016/j.obhdp.2019.09.003

Khosa, A., Burch, S., Ozdil, E., \& Wilkin, C. (2019). Current issues in PhD supervision of accounting and finance students: Evidence from Australia and New Zealand. The British Accounting Review, 100874. https://doi.org/https://doi.org/10.1016/j.bar.2019.100874

Paksi, Y. E. E., \& Prihartono, E. (2019). Sistem Monitoring Pemakaian Air Pdam Tirta Kencana Kota Samarinda Berbasis Arduino. JIMP-Jurnal Informatika Merdeka Pasuruan, 4(2).

Prasodjo, T. (2019). Knowledge Management: Sustainable Human Resource Development in Public Sector Organizations. Jurnal Ad'ministrare, 6(2), 159-166.

Pristiwaluyo, T., \& Ab Hakim, F. (2019). Pengaruh Kompetensi Kepribadian dan Kompetensi Sosial terhadap Pelaksanaan Supervisi Akademik Pengawas Sekolah Menengah Atas. Jurnal Ad'ministrare, 5(2), 63-76.

Siagian, S. P. (1989). Fungsi-fungsi manajerial. Bina Aksara.

Sufianto, A. (2015). Pengaruh Pengawasan Terhadap Efektifitas Kerja Pegawai Pada Kecamatan Samarinda Kota Di Kota Samarinda.

Suratman, Y. P. (2017). Taksonomi Konflik-Konflik Internal Di Indonesia Sebagai Potensi Perang Proxy (Taxonomy Of Internal Conflicts That Leads Into Proxy War In Indonesia). Jurnal Pertahanan \& Bela Negara, 7(1), 39-52.

Syamsiar, S., Saggaf, M. S., Salam, R., \& Ihsan, S. R. (2018). Implementation Of Supervision On Office Of Community Empowerment And Makassar City Village.

Syukur, M., \& Awaru, O. (2019). Opportunities and Challenges of Organic Agriculture in the Era of Industrial Revolution 4.0 (A Case Study at Bulukumba Regency; South Sulawesi Province). International Conference on Social Science 2019 (ICSS 2019).

Wildana, A., \& Awaru, A. O. T. (2018). Perilaku Akademik Aktivis (Studi Kasus Pada Mahasiswa Fis UNM Yang Aktif di Organisasi Daerah). JURNAL SOSIALISASI, 1-6. 
164| Jurnal Ilmiah Ilmu Administrasi Publik: Jurnal Pemikiran dan Penelitian Administrasi Publik Volume 1o Number 1, January - June 2020. Page 159-164 